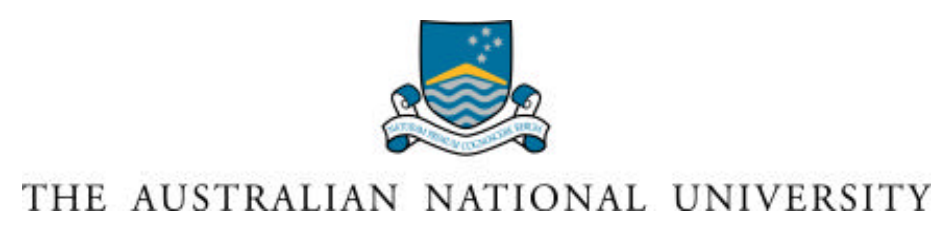

Working Paper Series in Finance 99/01

\title{
THEORY AND EVIDENCE ON THE RELATIONSHIP BETWEEN OWNERSHIP STRUCTURE AND CAPITAL STRUCTURE
}

\author{
Timothy J. Brailsford \\ Barry R. Oliver \\ Sandra L. H. Pua \\ Department of Commerce, Australian National University
}

JEL Classification

Keywords:

Last revision date:

Contact author:
G32

Ownership structure; Capital structure; Agency costs

July 1999

Barry Oliver

Department of Commerce

The Australian National University

Canberra ACT 0200 AUSTRALIA

Telephone: 0262490729 (International +61 26249 5005)

Facsimile: 0262490729 (International +61 26249 5005)

Email: barry.oliver@anu.edu.au

The working paper series is for manuscripts in draft form. Comments are welcome and should be sent to the contact author. Please do not quote without permission.

(C) Copyright 1999 T.J. Brailsford, B.R. Oliver and S.L.H. Pua 


\title{
THEORY AND EVIDENCE ON THE RELATIONSHIP BETWEEN OWNERSHIP STRUCTURE AND CAPITAL STRUCTURE
}

\author{
Timothy J. Brailsford \\ Barry R. Oliver \\ Sandra L. H. Pua
}

Department of Commerce, Australian National University, ACT, Australia 0200

\begin{abstract}
The agency relationship between managers and shareholders has the potential to influence decision-making in the firm which in turn potentially impacts on firm characteristics such as value and leverage. Prior evidence has demonstrated an association between ownership structure and firm value. This paper extends the literature by proposing a further link between ownership structure and capital structure. Using an agency framework we argue that the distribution of equity ownership among corporate managers and external blockholders has a significant relationship with leverage. The empirical results provide support for a positive relationship between external blockholders and leverage, and curvilinear relationship between the level of managerial share ownership and leverage. The results also suggest that the relationship between external block ownership and leverage varies across the level of managerial share ownership. These results parallel and are consistent with the 'active monitoring', 'convergence-of-interests' and the 'entrenchment' hypotheses.
\end{abstract}

Keywords: Ownership structure; Capital structure; Agency costs

JEL classification:G32

Corresponding author: Professor Tim Brailsford, Faculty of Economics and Commerce, Australian National University, Canberra ACT 0200, Australia

Tel: 612 6249-3596; Fax: 612 6249-0414; Email: Tim.Brailsford@anu.edu.au.

We acknowledge the constructive comments of Dave Allen and Sinclair Davidson. The financial assistance of ARC Research Grant S7969415 is acknowledged. 


\section{Introduction}

Since Modigliani and Miller's (1958) irrelevance proposition concerning capital structure choices and firm value, financial economists have devoted considerable attention to cross-sectional and time-series variations in capital structure. More recent work has looked to a managerial perspective in an attempt to provide an explanation for the variations in capital structure (eg. Barton and Gordon, 1988). Under the managerial perspective, the capital structure decision is not only determined by internal and external contextual factors which impact on the basic concerns of risk and controls, but the values, goals, preferences and desire of managers are also important inputs to the financing decision.

Employing the rationale underlying the agency theory framework, theoretical and empirical studies have suggested that managers, who have non-diversifiable human capital invested in the firm, have incentives to reduce their non-diversifiable employment risks by ensuring the continued viability of the firm (Amihud and Lev 1981). One method of reducing the non-diversifiable employment risk is by decreasing the firm's debt holdings (Friend and Lang 1988).

Recent developments in agency theory also suggest that the structure of corporate ownership can affect firm performance by mitigating agency conflicts between management and shareholders (Putterman 1993). Firms differ in terms of the degree to which ownership is concentrated among corporate insiders and external investors. Moreover, the distribution of ownership among different groups can impact on managerial opportunism which subsequently has implications for managerial behaviour and corporate performance.

The concept that the general characteristics of a firm's ownership structure can affect performance has received considerable attention but few studies have looked at the relationship between ownership structure and capital structure. ${ }^{1}$ This is despite good reasons to believe that there may be interrelations between the structures of ownership and capital. Specifically, the managerial approach to capital structure and the managerial self-interests hypothesis suggest that corporate financing decisions are influenced by managers' adverse incentives and the incentive for managers to act opportunistically can be influenced by the structure of equity ownership (Demsetz 1983, Shleifer and Vishny 1986, Agrawal

1 Recent empirical contributions on ownership structure and performance include Morck et al (1988), McConnell and Servaes (1990), Hermalen and Weisbach (1991), McConnell and Servaes (1995), Himmelberg et al (1999) and Cho (1998). 
and Mandelker 1990 and Prowse 1994). Consequently, the distribution of equity ownership may be related to capital structure.

This paper contributes to this area of research by investigating whether the structure of equity ownership can help explain cross-sectional variation in capital structure. Since corporate managers and external blockholders are two groups of shareholders who have an influence on decisions concerning the allocation of the firm's resources, we focus on the effects of managerial share ownership and external block ownership on managerial incentives and consequently on the leverage ratio. Moreover, despite the widespread interest in the way firms make their financing decisions, most of the capital structure research has been conducted in the United States. There is limited evidence outside the United States. $^{2}$

This paper uses an agency framework to develop several testable hypotheses. First, the external block ownership model identifies the effect of external block ownership on managers' incentives to reduce their non-diversifiable employment risks and adjust the corporate debt ratio. ${ }^{3}$ Second, the managerial share ownership model looks at the effect of management ownership on the level of debt. Third, we examine a model that incorporates the effects of both external block ownership and managerial share ownership on the corporate financing decision.

The paper is comprised as follows. Section two considers the role that external block ownership has on financing decisions while section three links managerial share ownership and external blockholders with capital structure. Section four provides details of the data and model specifications and section five presents the empirical results. Section six provides the results of sensitivity analysis and section seven concludes the paper.

2 For instance, with some exceptions including Chiarella et al (1992), Allen (1993) and Gatward and Sharpe (1996) there has generally been a lack of research in this area in Australia.

3 External block ownership has traditionally been defined as the share ownership by large non-managerial investors. 


\section{External Block Ownership and Capital Structure}

The literature concerning the role of block shareholders strongly suggests that external blockholders have incentives to monitor and influence management appropriately to protect their significant investments (Friend and Lang 1988, Mehran 1992). Due to their large economic stake, these investors have a strong desire to watch over management closely, making sure that management do not engage in activities that are detrimental to the wealth of shareholders. According to this 'active monitoring hypothesis', external blockholders reduce the scope of managerial opportunism, resulting in lower direct agency conflicts between management and shareholders (Shleifer and Vishny 1986). Shome and Singh (1995) obtain evidence which is consistent with the active monitoring hypothesis. They examine the market reaction to the announcement of acquisitions of large share parcels using event study methodology. Shome and Singh (1995) report significant positive abnormal returns associated with announcements of block acquisitions by external shareholders. Moreover, they show that the abnormal returns are positively associated with a reduction in agency costs (through proxy variables). Bethel et al (1998) find that long term operating performance of firms improves subsequent to the acquisition of a block by activist shareholders. More general empirical support for the notion that the capital structure decision is agency related is also provided by Johnson (1997) who reports that monitoring effects are influential in the debt decision and in the decision between public and private debt sources. Specific support is provided in Mehran (1992) who shows that leverage is positively related to, among other variables, the percentage of equity owned by large individual investors.

This above evidence is consistent with the reduction in agency conflicts when there are increases in external blockholdings. Consequently, if external blockholders serve as active monitors over the actions of corporate managers, management may not be able to adjust the debt ratio to their own interests as freely if such investors do not exist. Since the economic stake of blockholders increase as their share ownership rises, the incentives of blockholders to protect their investments and consequently monitor management can be expected to increase with the level of their share ownership. Moreover, as the share ownership of external blockholders increase, their voting power and influence increase, giving them greater ability to control the actions of managers. Hence, corporate debt ratios are likely to be an increasing function of the level of share ownership of external blockholders. This leads to the first hypothesis: Firms with a higher level of external blockholdings are likely to have a higher debt ratio, ceteris paribus.

Shleifer and Vishny's (1986) active monitoring hypothesis, however, has been challenged by Pound (1988) who argues that large shareholders may be passive voters who collude with corporate insiders against the best interests of dispersed shareholders. Evidence consistent with this 'passive voters hypothesis' is presented by McConnell and Servaes (1990) in relation to large shareholders and firm 
value. If this hypothesis more accurately describes the organisational role of external blockholders, corporate leverage may be negatively related to the share ownership of such blockholders. This paper therefore can also be seen as conducting an empirical test of two opposing hypotheses concerning the role which external blockholders play in influencing corporate capital structure.

\section{Managerial Share Ownership and Financing Decisions}

Jensen and Meckling (1976), Fama and Jensen (1983) and Shleifer and Vishny (1986), among others, have suggested that the structure of equity ownership has an important effect on managerial incentives and firm value. The literature initially assumes that most investors will prefer to invest in a welldiversified portfolio to minimise portfolio risk. Since the liabilities of a firm's shareholders are limited to their share ownership, risks can be diversified with other investments. However, corporate managers are unable to achieve the same minimum level of aggregate risk as a large proportion of their wealth is derived from the significant investment in human capital specific to the firm. Unlike financial capital, the risks associated with human capital are largely undiversifiable (Amihud and Lev, 1981). These non-diversifiable risks result in a welfare reduction (Crutchley and Hansen, 1989). This loss of diversification is particularly costly to corporate managers due to their personal wealth constraints.

Since risk averse managers bear an unavoidable burden of risk linked to the fortunes of the firm employing them, managerial self-interest advocates argue that once presented with opportunities, managers have incentives to lower the non-diversifiable employment risks by ensuring the continued viability of the firm (Amihud and Lev, 1981). This is known as the 'managerial self-interests hypothesis'.

One technique for reducing non-diversifiable employment risk is by decreasing the firms' debt holdings (Friend and Lang 1988). This is because debt increases the bankruptcy risks of a firm. Since the occurrence of bankruptcy or financial distress will result in loss of employment, potential impairment of future employment and potentially lower earnings capacity of managers, it is argued that selfinterested managers have incentives to reduce corporate debt to a level which is less than optimal. However, it is unlikely that management can reduce the debt level to zero due to the existence of corporate governance mechanisms to discipline and control their behaviour. Such mechanisms include the managerial labour market, capital market and market for corporate control. ${ }^{4}$

4 For instance, Fama and Jensen (1983) argue that stock prices are visible signs that summarise the implications of decisions about future net cash flows. This external governance device exerts pressure to 
Corporate debt policy has also been viewed as an internal control mechanism which can reduce agency conflicts between management and shareholders, particularly the agency costs of free cash flow as suggested by Jensen (1986). Jensen argues that managers with substantial amounts of free cash flow are more likely to engage in non-optimal activities. Grossman and Hart (1980) suggest that debt is a disciplinary device which can be used to reduce the agency costs of free cash flow. Specifically, the obligations associated with debt reduce management's discretionary control over the firm's free cash flow and their incentives to engage in non-optimal activities. ${ }^{5}$

Jensen and Meckling (1976) argue that managerial share ownership can reduce managerial incentives to consume perquisites, expropriate shareholders' wealth and to engage in other non-maximising behaviour and thereby helps in aligning the interests between management and shareholders. This is the 'convergence-of-interests' hypothesis.

The convergence of interests hypothesis has been challenged by Fama and Jensen (1983) and Demsetz (1983) who suggest that managerial share ownership may have adverse effects on agency conflicts

orient a firm's decision process toward the interests of shareholders. The market for corporate control has been suggested as one of the most effective corporate governance mechanisms (Manne 1965). If managers are not maximising the value of the firm, then any party could, in theory, purchase the firm, change the financing policy to a value maximising one and reap the resulting increase in value. Weisbach (1993) suggests that the main reason for a hostile takeover is to replace managers who are not maximising shareholder wealth. However, impediments in the market for corporate control are recognised. Prowse (1994), among others, suggest that takeovers may only be important in correcting the most serious cases of managerial laziness, incompetence or self interest behaviour. Further, while the managerial labour market may be sufficient to eliminate the incentive problems in perfect market conditions, market imperfections may cause it to be less than perfect. Morck et al (1988) argue that when managers hold a large proportion of the firm's shares, they generally have enough voting power, or influence, to guarantee their current employment and remuneration with the firm.

5 However as Myers (1977) demonstrates, debt can also have undesirable effects such as inducing managers to forego positive net present value projects. 
between management and shareholders due to the costs of significant managerial share ownership. They argue that instead of reducing managerial incentive problems, managerial share ownership may entrench the incumbent management team, leading to an increase in managerial opportunism.

The combination of the convergence of interests and entrenchment hypotheses suggest a curvilinear relationship between managerial share ownership and corporate value. Studies such as Morck et al (1988), McConnell and Servaes (1990) and McConnell and Servaes (1995) find a non-linear relationship between managerial share ownership and firm value. These studies suggest that at low levels of managerial share ownership, managerial share ownership increases firm value due to the convergence-of-interests effect. However, when the level of management ownership is high, entrenchment sets in, leading to higher agency conflicts and a consequent decline in the value of the firm. Morck et al (1988) using US data find a positive relation between management ownership and firm value (as measured by Tobin's Q) in the $0 \%$ to 5\% ownership range and beyond the $25 \%$ ownership range. McConnell and Servaes (1990), also using US data, find a positive relation between managerial share ownership and firm value but in the management ownership range of $0 \%$ to $40-50 \%{ }^{6}$ Short and Keasey (1999) provide support for the curvilinear effects but find that management in the United Kingdom become entrenched at higher levels of ownership than their United States counterparts. Kole (1995) argues that the variation in results in the United States may be driven by a size effect whereas Short and Keasey (1999) argue that governance mechanisms in the different countries may be a contributing factor in explaining the differences. Despite the possible connection between managerial share ownership and external block ownership in mitigating agency conflicts, prior studies have generally only examined the effect of either managerial share ownership or external block ownership on agency conflicts (and firm value) separately.

The above evidence demonstrates a link between managerial share ownership and firm value. Despite the irrelevance theory of Modigliani and Miller's (1958), the existence of market imperfections suggest a link between capital structure and firm value. Indeed, numerous studies confirm such a link. For instance McConnell and Servaes (1995) provide evidence that for firms with few growth opportunities, firm value (as measured by Tobin's Q) is positively correlated with leverage and for firms with high growth opportunities $\mathrm{Q}$ is negatively correlated with leverage. Hence, it is reasonable to argue that a link also exists between managerial share ownership and capital structure.

6 McConnell and Servaes (1995) replicate and extend their earlier study but over a later time period and obtain similar results to McConnell and Servaes (1990). 
Moreover, using the rationale behind the convergence-of-interests and entrenchment hypotheses, we argue that the relationship between managerial share ownership and debt ratio may also be curvilinear. Specifically, at low levels of managerial share ownership, managerial share ownership is likely to align management and shareholder interests, leading to increased debt levels. However, when managers already hold a significant portion of the firm's equity, an increase in managerial share ownership may lead to managerial entrenchment. In general, when the level of managerial share ownership is "too high", there will be few constraints on managerial behaviour, leading to an increase in managerial opportunism and decreased debt levels. Thus, it is predicted that the relationship between managerial share ownership and agency conflicts is curvilinear with the effects of managerial opportunism first decreasing, then increasing as managerial share ownership rises.

This leads to the second hypothesis: At low levels of managerial share ownership, managerial share ownership is positively related to a firm's debt ratio, ceteris paribus, and at high levels of managerial share ownership, managerial share ownership is negatively related to a firm's debt ratio, ceteris paribus, such that the expected relationship between management ownership and the leverage ratio is curvilinear.

The few studies that have examined this relationship have yielded inconsistent results. Friend and Lang (1988) find that the presence of managerial blockholders is associated with decreases in the debt level resulting in a negative relationship. They find that this relationship is independent of the presence of external blockholders although their tests do not directly address whether the relationship between external block ownership and the debt ratio varies with the level of managerial share ownership. Jensen et al (1992) also report a significant negative relationship between leverage and insider share ownership. However, this study does not consider the role of external blockholders. In contrast, Kim and Sorensen (1986) and Mehran (1992) both report a positive relationship between leverage and insider share ownership. Kim and Sorensen focus on the determinants of debt and use only a zero-one dummy variable for managerial share ownership. Their emphasis is on general agency costs rather than the specific effects of ownership structure.

Mehran (1992) speculates that the difference in the results may be attributable to different data sets. However, the method in these papers also varies. For instance, Mehran uses a linear regression model while Jensen et al (1992) use a system of equations and three-stage least squares. Of note, these studies all assume a linear (or logarithmic) functional form on the relationship. However, as argued above, a curvilinear (or quadratic) form can be justified by the theory. In this sense, our paper potentially provides a reconciliation of the inconsistent evidence, in addition to presenting a 
comprehensive test. It may be that at different levels of managerial share ownership, different signs are observed due to the non-linear form and the interaction between managerial and external block ownership. Hence, we suggest that existing studies may have employed mis-specified models. To illustrate, in Mehran's sample, the mean level of executive share ownership is $11.7 \%$ while in Jensen et al, the mean level of insider ownership is $16.5 \%$. The lower level being consistent with a more positive relationship.

It is further argued here that at low levels of managerial share ownership, external block ownership plays a significant role in monitoring the behaviour of management, resulting in lower managerial opportunism. With low levels of managerial share ownership managers have limited voting power and influence, while external blockholders have the ability to monitor and restrict managerial opportunistic behaviour, therefore mitigating agency conflicts. Consequently, both external block ownership and managerial share ownership have a positive effect on the managerial incentive problems. In particular, both factors are hypothesised to be able to reduce managerial opportunistic behaviour, such that external block ownership has a complementary effect at low levels of managerial share ownership. This interaction effect has not been previously considered. Hence, the third hypothesis follows: At low levels of managerial share ownership, the level of external block ownership is positively related to the firm's debt ratio, ceteris paribus.

At high levels of managerial share ownership, the monitoring effect of external block ownership is offset by the entrenchment effect arising from high managerial share ownership. Thus, the effectiveness of external block ownership on managerial opportunism may be significantly reduced. With managers having effective control, external blockholders may not have the ability to prevent selfinterested managers from indulging in non-maximising behaviour. As a result, external block ownership and managerial share ownership work in opposite directions at high levels of managerial share ownership.

If the entrenchment effect of managerial share ownership exceeds the monitoring effect of external block ownership, the significance of the relationship between external block ownership and leverage will be reduced. The extent of the reduction depends on the magnitude of the entrenchment effect. At the extreme, if the entrenchment effect dominates the monitoring effect, the relationship between external block ownership and leverage will be ineffective. Due to the confounding influences, it is not possible, a priori, to predict the specific relationship between external block ownership and leverage at high levels of managerial share ownership. However, what is known is that the relationship between external block ownership and leverage at high levels of managerial share ownership will not be as significant as compared to low levels of managerial share ownership. Again, this interaction has not 
been previously considered. This leads to the fourth and final hypothesis: The association between external block ownership and the firm's debt ratio is weakened in the presence of high levels of managerial share ownership, ceteris paribus.

\section{Data and Model Specification}

In order to investigate the relationship between the structure of equity ownership and corporate financing policies, a range of data are needed. The initial sample includes 216 Australian listed companies for which relevant financial data is available for the chosen sample period 1989 to 1995 . $^{7}$ Of this sample, 97 companies have a common accounting period ending at 30 June and a complete set of financial data.

For each sample firm, the following items are collected: (a) the share ownership of the top two, top five and all directors ${ }^{8}$; (b) the share ownership of the top two, top five and top 20 largest shareholders; and (c) the distribution of shareholders and their holdings. ${ }^{9}$

A further 48 companies are eliminated due to the unavailability of a complete set of share price and ownership information leaving a final sample of 49 firms. ${ }^{10}$

The dependent variable $(D / E)$ is defined as the natural bgarithm of the ratio of the book value of debt $\left(D_{B V}\right)$ to market value of equity $\left(E_{M V}\right){ }^{11}$ The natural $\log$ transformation is used to mitigate possible problems with the sample distribution of the ratio. ${ }^{12}$

7 Data are obtained from Datastream and the 'Annual Stockmarket Summaries for Taxation' compiled by the Australian Stock Exchange.

8 This includes both executive and non-executive directors.

9 The required data for the share ownership of corporate managers and external block holders are obtained from the Annual Report file of the Australian Graduate School of Management (AGSM) database.

10 Firms in the sample included both industrial and resource companies. Of the 49 firms in the final sample, 37 are industrial companies and 11 are resource companies.

11 Equity is defined as market value of equity. Book value of debt is used as a proxy for market value of debt due to problems in estimating market values of unlisted debt securities. Many studies have used book value of debt in measuring leverage (as examples see Friend and Lang 1988 and Titman and Wessels 
Six sets of explanatory variables are included in an attempt to capture different effects. The first set of explanatory variables comprise the ownership variables. Since a firm's capital structure is likely to be affected by many factors other than the allocation of equity ownership, the remaining five sets of variables are included in an attempt to control for these other effects. These variables are used to "isolate" the effects of the equity ownership on capital structure and include risk (three variables), agency cost (three variables), asset specificity (one variable) and tax (two variables).

\section{A. Model I}

Since the underlying hypothesis is that capital structure is a function of the distribution of equity ownership among managers and external blockholders, the firm's debt to equity ratio is regressed on various measures of ownership structure (and other control) variables. The first hypothesis proposes that firms with higher levels of external blockholdings will have higher leverage. This hypothesis is tested by regressing the dependent variable, $D / E$ against the external block ownership $(E B O)$ and control variables: ${ }^{13}$

$$
\begin{aligned}
D / E_{i t}= & \alpha_{0}+\beta_{0} E B O_{i t}+\beta_{1} S_{I Z E_{i t}}+\beta_{2} I N D_{i t}+\beta_{3} \text { VOLTY }_{i t}+\beta_{4} G_{R O W T H_{i t}}+\beta_{5} P_{R O F_{i t}}+\beta_{6} F C F_{i t} \\
& +\beta_{7} I N T A_{i t}+\beta_{8} N D T S_{i t}+\beta_{9} D I V_{i t}+\varepsilon_{i t}
\end{aligned}
$$

where:

it $\quad=$ the $i$ th firm in period $t$.

$D / E \quad=$ natural $\log$ transformation of Debt/Equity ratio.

$E B O=$ percentage of ordinary shares held by the larger shareholders. Data for the top two, five and 20 external shareholders are used as the proxy for external block ownership. ${ }^{14}$

1988). Bowman (1980) argues that even if the market value of debt is a more accurate measure of leverage, the use of book value of debt is not expected to distort leverage ratios.

12 We also run the models without the logarithmic transformation of the debt-equity ratio and the results are very similar to those reported and do not change any of the conclusions.

13 As the sample includes multi-year observations, there is likely to be induced heteroskedasticity. In view of the potential existence of heteroskedasticity, standard errors are constructed using White's (1980) heteroskedastic consistent variance-covariance matrix.

14 Sensitivity analysis is conducted on the impact of the top two, top five and top 20 external shareholders. Friend and Lang (1988) use a dummy variable to represent the existence of external block shareholders 
The three variables used to control for risk are:

SIZE $\quad=$ natural $\log$ (total assets) $^{15}$. This variable is expected to have a positive coefficient as larger more diversified firms are likely to have a lower risk of bankruptcy and can sustain a higher level of debt (Scott and Martin 1975, Ferri and Jones 1979, Friend and Lang 1988).

IND = zero-one dummy variable for industry classification, where IND $=1$ if industrial company and $I N D=0$ if natural resource company. ${ }^{16}$ It is argued that industry class is a potential determinant of capital structure because firms in the same industry face similar demand and supply conditions and thus have similar risk characteristics (Scott and Martin 1975, Ferri and Jones 1979). To some extent, the industry variable may also capture some of the effects of the "free cash flow" theory advanced by Jensen (1986). Jensen identifies some industries with significant potential for free cash flow abuses. However, we include a specific variable, (below) for free cash flow to isolate these effects.

VOLTY = the standard deviation of the annual percentage change in operating income before interest, taxes and depreciation (Bradley et al 1984). We use the previous three years when estimating standard deviation. It is suggested that since the volatility of a firm's future income is the chief factor in determining a firm's ability to meet interest charges, earnings volatility is an indication of business risk (Ferri and Jones 1979). Because debtholders look upon a firm's future earnings as a means of protection, an increase in the volatility of earnings decreases the supply of debt (Bradley et al 1984, Mehran 1992). Various measures are used in the literature to measure earnings volatility. Bradley et al (1984) use the standard deviation of the annual percentage

with a holding of $10 \%$ or more of a firm's outstanding stock. We extend Friend and Lang (1988) by using the proportion of outstanding shares owned by external block holders.

15 Many studies suggest that firm size is one important factor which affects a firm's debt policy and therefore risk (Scott and Martin 1975, Ferri and Jones 1979, Agrawal and Nagarajan 1990).

16 A more detailed industrial classification is not used because the increase in the number of dummy variables imposes too severe restriction on the degrees of freedom in the regression. 
change in cash flows (earnings before interest, depreciation and taxes). Titman and Wessels (1988) use operating income instead of cash flow in constructing their measure of earnings volatility.

The three variables used to control for agency costs are:

GROWTH = the annual percentage change in total assets. Kim and Sorensen (1986), Titman and Wessels (1988), Jensen et al (1992) and Mehran (1992) suggest that a firm's growth opportunities are a good proxy for the agency costs of debt. They suggest that the tendency to invest sub-optimally to expropriate wealth from a firm's debtholders is likely to be higher for firms in growing industries. On the other hand, growth may also be an indicator of profitability and success of the firm. If this is the case, GROWTH will be a proxy for available internal funds. If a firm is successful and earning profits, there should be sufficient internal funds available for investment. This may then be associated with Myers and Majluf (1984) "pecking order" theory, which suggests a negative coefficient on the GROWTH variable. Further, McConnell and Servaes (1995) suggest that the agency relationship induced by managerial share ownership differs between high and low growth firms.

$F C F \quad=O Y B T+D E P+A M O-T A X P A I D-D I V P A I D$

where:

$O Y B T=$ operating income before income tax

$D E P \quad=$ depreciation expense

$A M O=$ amortisation separately reported, such as goodwill

TAXPAID = total tax paid

DIVPAID $=$ total dividends paid

$F C F$ is a direct measure of Jensen's (1986) free cash flow hypothesis. The free cash flow hypothesis states that managers endowed with excessive free cash flows will invest sub-optimally rather than paying the free cash flow out to shareholders. Jensen (1986) predict that firms with excessive free cash flow are likely to have higher leverage. $F C F$ is defined in a similar manner to Lehn and Poulsen (1989).

PROF = operating income before interest and taxes scaled by total assets. Indicators of a firm's profitability include ratios of operating income over sales and operating income over total assets (Titman and Wessels 1988, Jensen et al 1992) and ratios of average earnings before interest and taxes over total assets (Wald 1995). Using a modified version of the "pecking order" hypothesis, Myers and Majluf (1984) relate profitability 
to capital structure by suggesting that more profitable firms will demand less debt because internal funds are available for finance. Since profitable firms have more earnings available for retention, these firms tend to build their equity relative to their debt. A number of empirical studies have examined the effect of profitability on firm leverage, including Friend and Lang (1988) and Jensen et al (1992). Generally, these studies find a negative association between profitability and leverage.

The variable used to control for asset specificity is:

INTA $=\underline{\text { Total Intangibles }}$

Total Assets

Balakrishnan and Fox (1993) argue that asset specificity creates problems for debt financing due to the non-redeployability characteristics of specific assets. More specifically, asset specificity adversely affects a firm's ability to borrow. Balakrishnan and Fox (1993) suggest that examples of firm-specific assets are intangible assets such as brand names, research and development expenditure and other reputational investments. The INTA variable may also capture a firm's discretionary investment opportunities. Myers (1977) argues that agency costs associated with intangibles assets are higher than those associated with tangible assets. To the extent that INTA picks up this effect, it will be negatively related to the $D / E$ ratio.

The last two explanatory variables are used to control for the effect of taxes:

NDTS $\quad=$ Annual Depreciation Expense

\section{Total Assets}

NDTS variable is used to capture the non-debt tax shield argument put forward by DeAngelo and Masulis (1980). They argue that the greater the level of non-debt tax shields, the lower is the benefit of additional debt. Thus, all else equal, firms with higher non-debt tax shields are expected to receive lower tax benefits from issuing debt and therefore will utilise less debt. DeAngelo and Masulis's (1980) argument therefore implies a negative relation between non-debt tax shields and the $D / E$ ratio. 
$=$ the weighted average percentage of franked dividends paid in a year as a fraction of total dividends paid. $D I V$ is an attempt to capture the effect of dividend imputation on a firm's financing decisions (Howard and Brown 1992). ${ }^{17}$ Under the imputation system, there is a need to distinguish between fully franked, partly franked and unfranked dividends. Unfranked dividends are effectively taxed under the classical tax system. The sign of the relationship between the $D I V$ variable and the $D / E$ ratio is unclear as it depends on the relationship between the company tax rate, personal tax rates and effective capital gains tax rates. As these may vary across shareholders and across shareholder groups, it is difficult to predict the sign of this second tax variable.

\section{B. Model II}

To test for the hypothesised curvilinear relationship between managerial share ownership and capital structure, the managerial share ownership variable and the square of managerial share ownership variable is augmented to the regression model:

$$
\begin{aligned}
D / E_{i t}= & \alpha_{0}+\beta_{0} M O_{i t}+\beta_{1}(M S O)^{2}{ }_{i t}+\beta_{2} S_{I Z E_{i t}}+\beta_{3} I N D_{i t}+\beta_{4} \text { VOLTY }_{i t}+\beta_{5} \text { GROWTH }_{i t} \\
& +\beta_{6} \text { PROF }_{i t}+\beta_{7} F_{C F}+\beta_{8} I N T A_{i t}+\beta_{9} N D T S_{i t}+\beta_{10} D I V_{i t}+\varepsilon_{i t}
\end{aligned}
$$

where:

MSO = percentage of ordinary shares owned by all executive and non-executive directors. ${ }^{18}$

Other variables are as previously described in Section A.

\section{Model III}

Finally, a joint test is used to investigate the third and fourth hypotheses which explore the relationship between external block ownership and leverage at different levels of managerial share ownership. Specifically, the third hypothesis predicts that external block ownership and debt are positively related when the level of managerial share ownership is low. The fourth hypothesis predicts that at high levels

17 In 1987, a dividend imputation tax system was introduced in Australia. Under this system Australian resident shareholders receive a credit for the tax paid at the corporate level on franked dividends. A franked dividend is defined as a dividend paid out of profits on which Australian corporate tax has already been paid.

18 Share ownership of corporate directors are used by Morck et al (1988) and Keasey et al (1994), amongst others to proxy for managerial share ownership. 
of managerial share ownership, the association between external block ownership and the firm's debt ratio is less significant than at low levels of managerial share ownership, since the positive monitoring effect of external block ownership is offset by the negative entrenchment effect associated with managerial share ownership.

To test these two hypotheses, a dummy variable $\Phi$, denoting different levels of managerial share ownership is employed where $\Phi$ takes the value of 0 if the level of managerial share ownership is less than $20 \%$. When managerial share ownership is $20 \%$ or more $\Phi$ takes the value of 1 . While there is generally little theoretical justification for the particular cut-off, the $20 \%$ level has been used in several previous studies. For example, Hermalin and Weisbach (1991) find that the entrenchment effect of managerial share ownership sets in after 20\% of managerial share ownership. Moreover, Chapter 6 of Australian Corporations Law uses a threshold of $20 \%$ ownership as the point at which further acquisition of shares can only be obtained via a prescribed takeover bid. ${ }^{19}$

The natural $\log$ of $D / E$ is then regressed against $M S O, M S O^{2}, E B O, \Phi E B O$ and the control variables:

$D / E_{i t} \quad=\alpha_{0}+\beta_{0} M S O_{i t}+\beta_{1} M S O_{i t}^{2}+\beta_{2} E B O_{i t}+\beta_{3}\left(\Phi E B O_{i t}\right)+\beta_{4} S I Z E_{i t}+\beta_{5} I N D_{i t}+\beta_{6} V O L T Y_{i t}+$

$$
\beta_{7} G R O W T H_{i t}+\beta_{8} P_{R O F_{i t}}+\beta_{9} F C F_{i t}+\beta_{10} I N T A_{i t}+\beta_{11} N D T S_{i t}+\beta_{12} D I V_{i t}+\varepsilon_{i t}
$$

The coefficient on the $E B O$ variable reflects the relation between external block ownership and the debt level when the level of managerial share ownership is low.

The coefficient on the $\Phi E B O_{i t}$ variable then reflects the difference in the external block ownership and leverage relationship between high and low levels of managerial share ownership.

In order to infer the relationship between external block ownership and leverage at high levels of managerial share ownership, the coefficient $\beta_{3}$ is added to the coefficient $\beta_{2}$. In other words, the sum of $\beta_{2}$ and $\beta_{3}$ gives the slope for the relationship between external block ownership and leverage when the level of managerial share ownership is high.

19 A turning point of $33.25 \%$ for the relationship between managerial share ownership and leverage is identified (from Table 2). This point is also used as a cut-off for low and high levels of managerial share ownership in sensitivity analysis. 


\section{Results}

The empirical analysis consists of a series of OLS regressions utilising the correction technique for unknown heteroskedasticity of White (1980). Summary univariate statistics are discussed below.

The minimum and maximum values of $D / E$ ratios for the sample firms range from $2.2 \%$ to $176 \%$ with an average of 53.5\%. The average total assets for the sample firms is A $\$ 1,648,045,487$ with a minimum and maximum of $\mathrm{A} \$ 12,015,000$ and $\mathrm{A} \$ 21,627,000,000$ respectively. Thus, the sample firms range in size although they could generally be considered as medium to large in the Australian environment.

The average level of external block ownership $(E B O)$ is $43.3 \%$ (median $=40.7 \%$ ) and ranges from $0.07 \%$ to $80.62 \%{ }^{20}$ Average share ownership of the top two and top 20 largest external shareholders are $28.7 \%$ and $64.8 \%$, respectively. Share ownership of the top two largest external shareholders range from $0.07 \%$ to $73.02 \%$. The minimum and maximum values of top 20 largest external share holders are $0.08 \%$ to $100 \%$ respectively.

The average level of managerial share ownership (MSO) for the sample firms is $10.65 \%$ (median $=$ $0.63 \%$ ), which is very similar to the average levels of $10.60 \%$ and $11.84 \%$ as reported by Morck et al (1988) and McConnell and Servaes (1990) respectively.

All control variables, except $D I V$, are positively skewed. In particular, these data are bounded by zero in most cases and therefore likely to exhibit positive skewness. Correlation analysis shows that some explanatory variables are significantly correlated. First, there is significant positive correlation between the SIZE and FCF variables (0.777). This may not be surprising since larger firms are expected to have higher free cash flow. ${ }^{21}$ The SIZE and MSO variables are also significantly negatively correlated (0.446). This statistic confirms the wealth constraint argument which suggests that the personal wealth constraint of corporate insiders is one important barrier to managerial share ownership. Specifically, as the size of the firm increases, it becomes more costly for managers to purchase a larger percentage of shares. A significant negative correlation between PROF and SIZE (-0.504) is also found. This implies

${ }^{20} E B O$ is initially defined as the proportion of share ownership of top five largest shareholders. Sensitivity is carried out for the top two and top 20 shareholders. These results are discussed in section six.

${ }^{21}$ Free cash flows have been identified in the literature as being in evidence in large, diversified firms (Berger and Ofek 1995, Smith and Kim 1994). 
that larger firms are less profitable. A significantly positive correlation between IND and PROF (0.357) suggests that certain industries are more profitable than others. Of note the correlation between $F C F$ and $P R O F$ is negative and insignificant. Finally, $P R O F$ and $D I V$ also have a significant positive correlation (0.312) which implies that profitable firms are more likely to issue fully franked dividends to their shareholders.

The significant correlation between these variables suggests that multicollinearity may be a potential problem in the analysis. The effect, if any, of this correlation between explanatory variables on the robustness of our empirical results is investigated and reported in section six.

Table 1 presents the regression results for the external block ownership test (that is, Model I). As can be seen from this table, there is supportive evidence of a positive relation between external block ownership and leverage. The coefficient on the $E B O$ variable is positive and statistically significant $(t=$ 2.32).

\section{INSERT TABLE 1}

This positive relation is consistent with the active monitoring hypothesis which suggests that large shareholders have greater incentives to monitor management due to their significant investment in the firm. The increased monitoring by external blockholders decreases managerial opportunism, leading to lower agency conflicts. The results obtained are also consistent with those of Friend and Lang (1988) and Mehran (1992) who obtain evidence that firms with large non-managerial investors have significantly higher average debt ratios than those without external blockholders. Our results do not support the passive voting hypothesis (Pound, 1988) which suggests that large shareholders vote with management without due regard to the interests of dispersed shareholders.

The overall regression explains approximately $40 \%$ of the variation in the dependent variable. Consistent with the size argument, the SIZE variable in the regression has a significant positive coefficient $(t$-statistic $=2.58)$, suggesting that larger firms have higher leverage. This is consistent with Scott and Martin (1975) and Ferri and Jones (1979) and empirical evidence obtained by Agrawal and Nagarajan (1990).

The coefficient on the VOLTY variable is negative and significant $(t$-statistic $=-2.75)$. This suggests that firms with higher earnings volatility have a lower debt capacity due to higher bankruptcy risks.

The significant negative coefficient on PROF ( $t$-statistic $=-3.23)$ is consistent with the pecking order hypothesis of Myers (1977) and Myers and Majluf (1984), and the empirical results of Titman and 
Wessels (1988), Friend and Lang (1988), Chiarella et al (1992), Allen (1993) and Wald (1995). The "pecking order" hypothesis suggests that profitable firms will demand less debt because internal funds are available for financing projects.

The IND variable which proxies for firm risk has a positive and significant coefficient $(t$-statistic $=$ 4.90). This is consistent with Scott and Martin (1975) and Bradley et al (1984). It also suggests that industrial companies have higher leverage than resource companies.

The coefficient on the GROWTH variable is negative and marginally significant $(t$-statistic $=-1.75)$. This is consistent with Bradley et al (1984), Mehran (1992) and Titman and Wessels (1988) who obtain a significant negative relationship between growth opportunities and firm's leverage.

The unanticipated negative but insignificant coefficient on FCF may be due to the fact that the independent variables included in the models overlap and capture more than one effect. In this case, a few variables may proxy for the effect of free cash flow simultaneously. In particular, besides capturing the profitability effect, $P R O F$ variable may also proxy for the effect of free cash flow. To the extent that some industries have significant potential for free cash flow abuse, the IND variable may also capture some of the free cash flow effects. As a result, the $F C F$ variable may only reflect the residual effects of free cash flow.

The coefficients on the tax variables are not significant. This supports the tax neutrality of capital structure under an imputation tax system (see Howard and Brown 1992).

The next stage of analysis involves testing the curvilinear relationship as proposed in the second hypothesis. Table 2 contains the regression results of the curvilinear model where $D / E$ is regressed against managerial share ownership (MSO), the square of managerial share ownership $\left(M S O^{2}\right)$ and control variables. The coefficient on $M S O$ is positive but insignificant. The coefficient on $M S O^{2}$ is negative and significant $(t=-2.05) .{ }^{22}$ These results support the second hypothesis.

\section{INSERT TABLE 2}

22 To test for the possibility of a cubic relationship between managerial share ownership and leverage, the cube of managerial share ownership $\left(\mathrm{MSO}^{3}\right)$ is included in a regression model. The results show no supportive evidence of a cubic relationship. Specifically, the $M S O, M S O^{2}$ and $M S O^{3}$ coefficients are all statistically insignificant $(t$-statistics $=1.54,-1.26,0.91$ respectively) . 
The signs on $M S O$ and $M S O^{2}$ parallel the alignment of interests and entrenchment effects of managerial share ownership put forward by Jensen and Meckling (1976) and Fama and Jensen (1983) respectively. Specifically, when the level of managerial share ownership is low, an increase in managerial share ownership has the effect of aligning management and shareholders' interests. Consequently, as managerial share ownership increases from a low level, managers have less incentive to reduce the debt level, resulting in a higher level of debt (but at a decreasing rate). However, when corporate managers hold a significant proportion of a firm's shares, the entrenchment effect sets in, resulting in higher managerial opportunism and therefore a lower debt ratio. In particular, with significant voting power and influence, it becomes more difficult to control managerial behaviour, resulting in fewer constraints on managers' ability to adjust debt ratios to their own self-interests.

Overall this curvilinear regression model explains approximately $40 \%$ of the variation in the dependent variable. Several of the control variables, including SIZE, IND, VOLTY, GROWTH and PROF have statistically significant coefficients at either $5 \%$ or $10 \%$ levels. Moreover, the signs are consistent with predictions. Indeed, all coefficient signs, except $F C F$, are as hypothesised. The coefficient on $F C F$ is statistically insignificant. Again, the coefficients on the tax variables are not significant.

The turning point of the quadratic relationship can be found by evaluating the first derivative and setting it to zero. Our turning point is $33.25 \%$. This result has practical import as managerial share ownership in excess of $33.25 \%$ is associated with implied restrictions on the amount of leverage a firm can support, on average.

Previously, we separately tested the effect of external block ownership and managerial share ownership on capital structure and found that both have a significant impact on corporate financing policies. While external blockholders have a positive effect on the debt ratio, the relation between managerial share ownership and leverage is curvilinear. This implies that the debt ratio is a function of both managerial share ownership and external block ownership. Thus, we now explore a model which brings together both $E B O$ and $M S O$ (and the control) variables.

The regression results for the joint test are presented in Table 3. The results support the third and fourth hypotheses which propose that the relationship between external block ownership and leverage at high levels of managerial share ownership differs from that at low levels of managerial share ownership. The results of the joint model retain support for the curvilinear relationship between managerial share ownership and leverage. The coefficients on $M S O(t$-statistic $=2.61)$ and $M_{S O}^{2}(t$ statistic $=-3.40)$ are significantly positive and negative respectively. The coefficient on the $E B O$ 
variable tests the relationship between external block ownership and debt levels when the level of managerial share ownership is low, it is positive and significant $(t$-statistic $=3.17)$. The coefficient on the $E B O$ dummy variable is also significant $(t$-statistic $=-1.69)$ which indicates that the relationship between external block ownership and leverage is different at high and low levels of managerial share ownership. Specifically, the slope coefficient for the relationship between external block ownership and leverage at high levels of managerial share ownership is approximately zero (which is obtained from the summation of $\beta_{2}$ and $\beta_{3}$ ). It is argued that the positive monitoring effect of external blockholders is offset by the negative entrenchment effect arising from high levels of managerial share ownership.

\section{INSERT TABLE 3}

Overall, the regression results support our proposition that the relationship between external block ownership and leverage at low levels of managerial share ownership is different from that at high levels due to the interaction between managerial share ownership and external block ownership.

The signs on the majority of the control variables, including SIZE, IND, VOLTY, GROWTH and $P R O F$, are consistent with our predictions and the coefficients are statistically significant. However, the negative coefficient on $F C F$ is different from that anticipated. Further, the coefficients on the tax variables are again insignificant.

\section{Sensitivity Analysis}

The empirical tests to date have used the full sample which includes pooled multi-year observations (1989 to 1995). A shortcoming of using "pooled" data is that individual year observations may not be independent. More specifically, the time-series correlation between observations may yield spurious regression results. This section examines the robustness of our regression results by analysing subperiods. In particular, the full sample is divided into two sub-samples, with one comprising observations from 1989 to 1992 and the other comprising observations from 1993 to 1995. The regressions for the external block ownership test, managerial share ownership test and the joint model are then repeated using these sub-samples.

The regression results for the external block ownership test using the two sub-samples are similar to those using the full sample. The $E B O$ coefficient is positive in both sub-samples, but insignificant in the second sub-period. There are also similar results obtained for the coefficients across sub-samples relative to the full sample. The coefficients on DIV, NDTS and INTA remain insignificant across the samples, while the coefficients on IND and VOL remain significant with similar signs across both subsamples. 
The regression results of the managerial share ownership test using the two sub-samples provide consistent evidence of a curvilinear relationship as proposed by hypothesis two. The coefficient on the $M S O$ variable is positive and significant for both sub-samples but the $M S O^{2}$ variable has a negative coefficient but is insignificant in both sub-samples.

In the joint model, the results for the second sub-period are very similar to the full sample both in sign and significance on all variables except INTA. However, the first sub-period does not provide as consistent results. Although the sign on many coefficients is consistent, the significance varies. While this suggests that the relationship between managerial share ownership and leverage may vary across time, it may also be due to the smaller sample sizes of the two sub samples of approximately ninety observations.

One issue raised in the above discussion is the presence of significant correlation between some of the explanatory variables. It has been suggested that this correlation may create a problem of multicollinearity, and consequently model misspecification. The problem with multicollinearity is essentially the lack of sufficient information in the sample to permit accurate estimation of the individual parameters. It has been suggested that multicollinearity need not necessarily create a problem (Maddala, 1992). One way of testing for the impact of multicollinearity is by dropping the explanatory variables which are highly correlated. Hence, the highly correlated variables are removed one at a time to test the sensitivity of the results. First, we exclude from the full model the SIZE variable which is highly correlated with the $M S O, M S O^{2}, P R O F, F C F$, INTA, NDTS, and DIV variables (Model A). Next, we exclude the SIZE variable and the $F C F$ variable due to its high correlation with $M S O, M S O^{2}$, SIZE, PROF, INTA and NDTS variables (Model B). Finally, we exclude the SIZE and FCF variables along with the DIV variable due to its high correlation with SIZE, IND, PROF and INTA variables (Model C). Table 4 presents these results.

\section{INSERT TABLE 4}

From Table 4, it can be seen the regression results of Models A, B and C are very similar to those of the joint model as presented in Table 3. In particular, the coefficients on $M S O$ and $M S O^{2}$ in all three models are positive and negative respectively and are statistically significant. The $E B O$ coefficient estimate for all models is significantly positive. The coefficient on the $E B O$ dummy variable becomes insignificant when SIZE, FCF and DIV variables are omitted however, the sign remains consistent across all models. All other coefficients are similar to those of the joint model, except $F C F$. When the SIZE variable is omitted, the coefficient on the $F C F$ variable becomes insignificant and reverses in sign. 
Next, we test the robustness of the empirical results to alternative variable definitions. Previous studies have used various measures of ownership variables to proxy for external blockholdings and managerial share ownership. For example, Friend and Lang (1988) use the holdings of the largest single insider to proxy for insider ownership; Keasey et al (1994) employ the share ownership of all directors and Agrawal and Mandelker (1987), as does Mehran (1992), use three measures: share ownership of a single director, top two directors and all directors. The definitions of managerial share ownership and external block ownership in this paper have been the proportion of share ownership of all directors and proportion of share ownership of five largest shareholders respectively. To test the sensitivity of the results we use the share ownership of the top two and top 20 shareholders as an alternative for $E B O$.

The models are re-estimated using these alternative ownership proxies. The regressions yield very similar results. However, the coefficient on the $E B O$ dummy variable loses its significance when either the top 2 or the top 20 share ownership is used. Specifically, when the top two largest shareholders is used as the measure of $E B O$ in the joint model, the coefficient on $E B O$ remains positive and significant $(t$-statistic $=3.09)$. The $M S O$ and $M S O^{2}$ variables have significant positive $(t$-statistic $=1.89)$ and negative ( $t$-statistic $=-2.76)$ coefficients respectively. When the top 20 largest shareholders is used as the proxy for $E B O$ in the joint model, the coefficient of $E B O$ remains positive and significant ( $t$-statistic = 2.89). The coefficient on $M S O^{2}$ is significant and negative $(t$-statistic $=-1.87)$. However, the coefficient on $M S O$ while having the correct sign loses its significance $(t$-statistic $=1.25)$.

When the share ownership of top two directors is used as the proxy for MSO, the coefficient on the $E B O$ dummy variable (defined as the share ownership of the top 5 shareholders) is significant (tstatistic $=-1.95)$ as is the coefficient on $E B O(t$-statistic $=3.10)$. The coefficients on $M S O$ and $M S O^{2}$ have correct signs and are statistically significant $(t$-statistic $=1.97$ and -2.12$)$. When the share ownership of the top 5 directors is used, the coefficient on $E B O$ is significant $(t$-statistic $=3.18)$ but the coefficient on $E B O$ dummy is insignificant ( $t$-statistic $=-1.16$ ). The coefficients on $M S O$ and $M S O^{2}$ remain positive $(t$-statistic $=1.67)$ and negative $(t$-statistic $=-2.96)$ respectively.

The empirical analysis up to this point does not consider non-normality in the regression residuals. A Jarque-Bera test indicates significant non-normality in all regressions. Extreme observations are removed with the result that non-normality in residuals can not be rejected. A total of 19 extreme observations are identified through plots of the residuals. When these 19 observations are removed the $E B O$ variable loses significance in Model I $(t$-statistic $=0.32)$. The $M S O$ and the $M S O^{2}$ variables are significant in Model II ( $t$-statistic $=2.47$ and -3.83). In Model III the coefficients on the $E B O$ and $E B O$ dummy variables are both significant $(t$-statistic $=2.18$ and -1.75$)$. The coefficients on $M S O$ and the 
$M^{2} O^{2}$ variables are also significant $(t$-statistic $=3.53$ and -4.99$)$. These results provides strong confirmation of our main hypotheses.

\section{Summary and Conclusions}

Recent developments in agency theory suggest that the structure of corporate ownership can affect firm performance by mitigating agency conflicts between management and shareholders. In this paper we extend the agency framework and test hypotheses which concern the relationship between ownership structure and capital structure. The results provide evidence that the distribution of equity ownership among corporate managers and external blockholders has a significant relationship with leverage. The empirical results suggest that the level of external block ownership is positively related to leverage. This provides support for the active monitoring hypothesis which proposes that external blockholders have greater incentives and an ability to monitor management, thereby reducing managerial opportunism which may otherwise reduce leverage to a sub-optimal level in order to reduce management's non-diversifiable employment risk.

The results also indicate a curvilinear relationship between the level of managerial share ownership and leverage with the relationship reaching a maximum at $33.25 \%$ of management share ownership. This result parallels the convergence-of-interests and entrenchment hypotheses. In particular, at low levels of managerial share ownership, managerial share ownership has the effect of aligning shareholder and management interests. However, when managerial share ownership reaches a certain point (33.25\% on average in our sample) the entrenchment effect dominates the convergence-of-interests effect, leading to an increase in managerial opportunistic behaviour and an associated decrease in the debt level.

Furthermore, we find that the relation between external block ownership and leverage varies across the level of managerial share ownership. Specifically, it was predicted and found that at low levels of managerial share ownership, the "monitoring effect" of external block ownership is coupled with the "convergence-of-interests" effect of managerial share ownership, resulting in a positive relationship between external block ownership and leverage. However, at high levels of managerial share ownership, managerial entrenchment competes with external blockholders' monitoring such that the significance of external block ownership is substantially removed.

In a series of sensitivity tests, we show that our results are generally robust to alternative periods, model specification, alternative variable definition and the presence of outliers.

The results have considerable implication regarding the capital structure debate. By arguing for a link between the ownership structure and capital structure and through empirical support, this paper adds to 
an understanding of cross-sectional, and possibly time-series, variation in capital structure. The practical import is that ownership structure is related to the financial efficiency of a firm and hence decisions regarding the issue of equity need to consider a range of implications. These results may also help further explain the link between equity ownership, firm value and leverage. However, further developments on this link is left for future research.

As a final but important comment, a caveat needs to be issued in relation to causation. First, while our story proposes that ownership structure affects the leverage ratio, it is plausible that as the leverage ratio is determined by many other factors, the resultant leverage decision then impacts upon how ownership is structured. Certainly, firms can to some extent control the level of managerial share ownership although control over the existence of external blockholders is more difficult. Second, while we have demonstrated a link between ownership structure and capital structure, there are other interactions that are relevant such as firm value, managerial compensation and the general internal contracting environment. There is a question over the possible endogeneity of ownership (Cho, 1998) in which case causality and the directional relationship between the various factors is not easily established. 


\section{Table 1}

\section{OLS Regression Estimates For External Block Ownership Test}

\section{Model I:}

$$
D / E_{i t}=\alpha_{0}+\beta_{0} E B O_{i t}+\beta_{1} \text { SIZE }_{i t}+\beta_{2} I N D_{i t}+\beta_{3} \text { VOLTY }_{i t}+\beta_{4} G R O W T H_{i t}+\beta_{5} P R O F_{i t}+\beta_{6} F C F_{i t}+\beta_{7} I N T A_{i t}+\beta_{8} N D T S_{i t}+\beta_{9} D I V_{i t}+\varepsilon_{i t}
$$

Variables defined as: $\mathrm{D} / \mathrm{E}$ is the natural logarithm of the book value of debt to the market value of equity at financial year-end; EBO is the percentage of ordinary shares held by the largest five shareholders; SIZE is the natural logarithm of the book value of total assets; IND is a zero-one dummy variable that takes on the value of unity if the firm is in the industrial sector and zero otherwise; VOLTY is the standard deviation of the annual percentage change in operating income before interest, taxes and depreciation estimated over the previous three years; GROWTH is the annual percentage change in the book value of total assets estimated over the previous three years; PROF is the operating income before interest and taxes scaled by the book value of total assets at financial year-end; FCF is the operating income before tax plus depreciation and amortization less taxes and dividends paid; INTA is the total intangibles divided into total assets at financial year-end; NDTS is the annual depreciation expense divided into total assets at financial year-end; DIV is the weighted average percentage of franked dividends paid in the year as a fraction of total dividends paid. Sample based on Australian firms over the period 1989 to 1995.

\begin{tabular}{|c|c|c|c|}
\hline Variables & \multicolumn{2}{|c|}{$\begin{array}{l}\text { Coefficient } \\
\text { Estimates }\end{array}$} & $\begin{array}{l}\text { White's } \\
t \text {-statistic }\end{array}$ \\
\hline CONSTANT & $\alpha_{0}$ & -4.3483 & $-3.09 * *$ \\
\hline EBO & $\beta_{0}$ & 0.0080 & $2.32 * *$ \\
\hline SIZE & $\beta_{1}$ & 0.1639 & $2.58 * *$ \\
\hline IND & $\beta_{2}$ & 0.7116 & $4.91 * *$ \\
\hline VOLTY & $\beta_{3}$ & -0.0000 & $-2.75^{* *}$ \\
\hline GROWTH & $\beta_{4}$ & -0.0009 & $-1.75^{*}$ \\
\hline PROF & $\beta_{5}$ & -2.8316 & $-3.23 * *$ \\
\hline$F C F$ & $\beta_{6}$ & -0.0000 & -1.10 \\
\hline INTA & $\beta_{7}$ & -0.4412 & -1.32 \\
\hline NDTS & $\beta_{8}$ & -1.1506 & -0.51 \\
\hline$D I V$ & $\beta_{9}$ & -0.0000 & -0.07 \\
\hline
\end{tabular}

Adjusted $\mathrm{R}^{2}=0.37, \mathrm{~F}=11.92 * *$

** Significant at $5 \%$, Significant at $10 \%$ 
Table 2

OLS Regression Estimates For Managerial Share Ownership Test: Curvilinear Form

Model II:

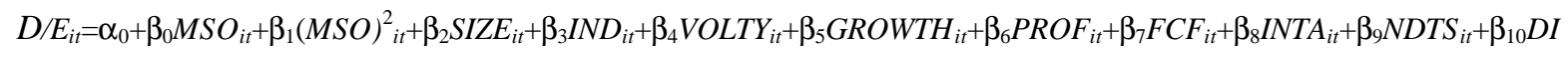

$$
V_{i t}+\varepsilon_{i t}
$$

Variables defined as: D/E is the natural logarithm of the book value of debt to the market value of equity at financial year-end; MSO is the percentage of ordinary shares held by all executive and non-executive directors; SIZE is natural logarithm of the book value of total assets; IND is a zero-one dummy variable that takes on the value of unity if the firm is in the industrial sector and zero otherwise; VOLTY is the standard deviation of the annual percentage change in operating income before interest, taxes and depreciation estimated over the previous three years; GROWTH is the annual percentage change in the book value of total assets estimated over the previous three years; PROF is the operating income before interest and taxes scaled by the book value of total assets at financial year-end; FCF is the operating income before tax plus depreciation and amortization less taxes and dividends paid; INTA is the total intangibles divided into total assets at financial year-end; NDTS is the annual depreciation expense divided into total assets at financial year-end; DIV is the weighted average percentage of franked dividends paid in the year as a fraction of total dividends paid. Sample based on Australian firms over 1989 to 1995.

\begin{tabular}{|c|c|c|c|}
\hline Variables & \multicolumn{2}{|c|}{$\begin{array}{l}\text { Coefficient } \\
\text { Estimates }\end{array}$} & $\begin{array}{l}\text { White's } \\
t \text {-statistic }\end{array}$ \\
\hline CONSTANT & $\alpha_{0}$ & -3.3052 & $-2.37 * *$ \\
\hline MSO & $\beta_{0}$ & 0.0133 & 1.44 \\
\hline$M S O^{2}$ & $\beta_{1}$ & -0.0002 & $-2.05 * *$ \\
\hline SIZE & $\beta_{2}$ & 0.1298 & $1.97 *$ \\
\hline$I N D$ & $\beta_{3}$ & 0.6666 & $5.17 * *$ \\
\hline VOLTY & $\beta_{4}$ & -0.0000 & $-3.82 * *$ \\
\hline GROWTH & $\beta_{5}$ & -0.0009 & $-2.00 * *$ \\
\hline PROF & $\beta_{6}$ & -3.4096 & $-3.83 * *$ \\
\hline$F C F$ & $\beta_{7}$ & -0.0000 & -1.07 \\
\hline INTA & $\beta_{8}$ & -0.0238 & -0.07 \\
\hline NDTS & $\beta_{9}$ & -1.2653 & -0.52 \\
\hline$D I V$ & $\beta_{10}$ & 0.0005 & 0.47 \\
\hline
\end{tabular}

Adjusted $\mathrm{R}^{2}=0.37, \mathrm{~F}=10.94 * *$

** Significant at $5 \%, *$ Significant at $10 \%$ 
Table 3

\section{OLS Regression Estimates For Joint Test}

\section{Model III:}

$D / E_{i t}=\alpha_{0}+\beta_{0} M S O_{i t}+\beta_{1} M S O^{2}{ }_{i t}+\beta_{2} E B O_{i t}+\beta_{3}\left(\Phi E B O_{i t}\right)+\beta_{4} S I Z E_{i t}+\beta_{5} I N D_{i t}+\beta_{6} V O L T Y_{i t}+\beta_{7} G R O W T H_{i t}+\beta_{8} P R O F_{i t}+\beta_{9} F C F_{i t}+\beta_{10} I N$

$$
T A_{i t}+\beta_{11} N D T S_{i t}+\beta_{12} D I V_{i t}+\varepsilon_{i t}
$$

Variables defined as: D/E is the natural logarithm of the book value of debt to the market value of equity at financial year-end; MSO is the percentage of ordinary shares held by all executive and non-executive directors; EBO is the percentage of ordinary shares held by the largest five shareholders; $\Phi$ is a zero-one dummy variable that takes on the value of unity if the level of managerial share ownership is greater than or equal to $20 \%$ and zero otherwise; SIZE is the natural logarithm of the book value of total assets; IND is a zero-one dummy variable that takes on the value of unity if the firm is in the industrial sector and zero otherwise; VOLTY is the standard deviation of the annual percentage change in operating income before interest, taxes and depreciation estimated over the previous three years; GROWTH is the annual percentage change in the book value of total assets estimated over the previous three years; PROF is the operating income before interest and taxes scaled by the book value of total assets at financial year-end; FCF is the operating income before tax plus depreciation and amortization less taxes and dividends paid; INTA is the total intangibles divided into total assets at financial year-end; NDTS is the annual depreciation expense divided into total assets at financial year-end; DIV is the weighted average percentage of franked dividends paid in the year as a fraction of total dividends paid. Sample based on Australian firms over 1989 to 1995.

\begin{tabular}{|c|c|c|c|}
\hline Variables & \multicolumn{2}{|c|}{$\begin{array}{l}\text { Coefficient } \\
\text { Estimates }\end{array}$} & $\begin{array}{l}\text { White's } \\
t \text {-statistic }\end{array}$ \\
\hline CONSTANT & $\alpha_{0}$ & -5.2110 & $-3.55^{* *}$ \\
\hline MSO & $\beta_{0}$ & 0.0362 & $2.61 * *$ \\
\hline$M S O^{2}$ & $\beta_{1}$ & -0.0004 & $-3.40 * *$ \\
\hline$E B O$ & $\beta_{2}$ & 0.0119 & $3.17 * *$ \\
\hline ФЕВО & $\beta_{3}$ & -0.0138 & $-1.69 *$ \\
\hline SIZE & $\beta_{4}$ & 0.1921 & $2.93 * *$ \\
\hline$I N D$ & $\beta_{5}$ & 0.8370 & $6.34 * *$ \\
\hline VOLTY & $\beta_{6}$ & -0.0000 & $-2.77 * *$ \\
\hline GROWTH & $\beta_{7}$ & -0.0015 & $-3.56^{* *}$ \\
\hline PROF & $\beta_{8}$ & -2.8245 & $-3.25 * *$ \\
\hline$F C F$ & $\beta_{9}$ & -0.0000 & $-2.28 * *$ \\
\hline INTA & $\beta_{10}$ & 0.0736 & 0.23 \\
\hline NDTS & $\beta_{11}$ & -2.1507 & -1.01 \\
\hline$D I V$ & $\beta_{12}$ & 0.0007 & 0.73 \\
\hline
\end{tabular}

Adjusted $\mathrm{R}^{2}=0.41, \mathrm{~F}=10.75^{* *}$

** Significant at $5 \%, *$ Significant at $10 \%$ 
Table 4

\section{Comparison of full model and models with excluded independent variables}

Model III:

$$
D / E_{i t=} \alpha_{0}+\beta_{0} M S O_{i t}+\beta_{1} M S O_{i t}^{2}+\beta_{2} E B O_{i t}+\beta_{3}\left(\Phi E B O_{i t}\right)+\sum \beta_{\mathrm{i}}(\text { control variables })+\varepsilon_{i t}
$$

Variables defined as: D/E is the natural logarithm of the book value of debt to the market value of equity at financial year-end; MSO is the percentage of ordinary shares held by all executive and non-executive directors; EBO is the percentage of ordinary shares held by the largest five shareholders; $\Phi$ is a zero-one dummy variable that takes on the value of unity if the level of managerial share ownership is greater than or equal to $20 \%$ and zero otherwise; SIZE is natural logarithm of the book value of total assets; IND is a zero-one dummy variable that takes on the value of unity if the firm is in the industrial sector and zero otherwise; VOLTY is the standard deviation of the annual percentage change in operating income before interest, taxes and depreciation estimated over the previous three years; GROWTH is the annual percentage change in the book value of total assets estimated over the previous three years; PROF is the operating income before interest and taxes scale $\mathrm{d}$ by the book value of total assets at financial year-end; FCF is the operating income before tax plus depreciation and amortization less taxes and dividends paid; INTA is the total intangibles divided into total assets at financial year-end; NDTS is the annual depreciation expense divided into total assets at financial year-end; DIV is the weighted average percentage of franked dividends paid in the year as a fraction of total dividends paid. Sample based on Australian firms over the period 1989 to 1995.

\begin{tabular}{|c|r|r|r|r|}
\hline Variables & $\begin{array}{r}\text { Model III } \\
\text { (Table 3) }\end{array}$ & Model (A) & Model (B) & Model (C) \\
\hline Adjusted R ${ }^{2}$ & 0.41 & 0.37 & 0.37 & 0.37 \\
\hline CONSTANT & -5.2110 & -1.0368 & -1.0270 & -1.0074 \\
& $(-3.55)^{* *}$ & $(-4.49)^{* *}$ & $(-4.42)^{* *}$ & $(-4.38)^{* *}$ \\
\hline MSO & 0.0362 & 0.0220 & 0.0221 & 0.0218 \\
& $(2.61)^{* *}$ & $(1.66)^{* *}$ & $(1.68)^{*}$ & $(1.67)^{* *}$ \\
\hline MSO $\boldsymbol{O}^{2}$ & -0.0004 & -0.0002 & -0.0002 & -0.0002 \\
& $(-3.40)^{* *}$ & $(-2.28)^{* *}$ & $(2.38)^{* *}$ & $(-2.38)^{* *}$ \\
\hline $\boldsymbol{E B O}$ & 0.0119 & 0.0084 & 0.0087 & 0.0087 \\
& $(3.17)^{* *}$ & $(2.43)^{* *}$ & $(2.51)^{* *}$ & $(2.52)^{* *}$ \\
\hline SEBO & -0.0138 & -0.0122 & -0.0127 & -0.0125 \\
& $(-1.69)^{*}$ & $(-1.45)$ & $(-1.50)$ & $(-1.49)$ \\
\hline SIZE & 0.1921 & Omitted & Omitted & Omitted \\
& $(2.93)^{* *}$ & & & \\
\hline IND & 0.8369 & 0.7405 & 0.7974 & 0.8021 \\
& $(6.34)^{* *}$ & $(5.37)^{* *}$ & $(5.68)^{* *}$ & $(5.60)^{* *}$ \\
\hline VOLTY & -.0000 & -0.000 & -0.0000 & -0.0000 \\
& $(-2.77)^{* *}$ & $(-4.09)^{* *}$ & $(-4.66)^{* *}$ & $(-4.70)^{* *}$ \\
\hline GROWTH & -0.0015 & -0.0017 & -0.0019 & -0.0019 \\
& $(-3.56)^{* *}$ & $(-3.92)^{* *}$ & $(-5.03)^{* *}$ & $(-4.79)^{* *}$ \\
\hline PROF & -2.8245 & -3.8474 & -3.9943 & -3.96 \\
& $(-3.25)^{* *}$ & $(-5.32)^{* *}$ & $(-5.66)^{* *}$ & $(-5.66)^{* *}$ \\
\hline FCF & -0.0000 & 0.0000 & Omitted & Omitted \\
& $(-2.28)^{* *}$ & $(1.30)$ & & \\
\hline INTA & 0.0736 & -0.0267 & 0.0870 & 0.0667 \\
& $(0.23)$ & $(-0.07)$ & $(0.26)$ & $(0.19)$ \\
\hline NDTS & -2.1507 & -2.3608 & -2.5479 & -2.5163 \\
& $(-1.01)$ & $(-0.97)$ & $(-1.06)$ & $(-1.05)$ \\
\hline DIV & 0.0007 & 0.0003 & 0.0003 & Omitted \\
& $(0.73)$ & $(0.33)$ & $(0.37)$ & \\
\hline & & & & \\
\hline
\end{tabular}

** Significant at 5\%

* Significant at $10 \%$ 


\section{References}

Agrawal, A. and G. Mandelker. "Managerial incentives and corporate investment and financing decisions." Journal of Finance, 42(4) (1987), 823-837.

Agrawal, A. and G. Mandelker. "Large shareholders and the monitoring of managers: The case of antitakeover charter amendments." Journal of Financial and Quantitative Analysis, 25(2) (1990), $143-161$.

Agrawal, A. and N. Nagarajan. "Corporate capital structure, agency costs, and ownership control: The case of all-equity firms.” Journal of Finance, 45(4) (1990), 1325-1331.

Allen, D. "The pecking order hypothesis: Australian evidence." Applied Financial Economics, 3(2) (1993), 101-112.

Amihud, Y. and B. Lev. "Risk reduction as a managerial motive for conglomerate mergers." Bell Journal of Economics, 12(2) (1981), 605-617.

Balakrishnan, S. and I. Fox. "Asset specificity, firm heterogeneity and capital structure." Strategic Management Journal, 14 (1993), 3-16.

Barton, S. and P. Gordon. "Corporate strategy and capital structure." Strategic Management Journal, 9 (1988), 623-632.

Berger, P. and E. Ofek. "Diversification's effect on firm value." Journal of Financial Economics, 37 (1995), 39-65.

Berger, P., Ofek, E. and D. Yermack. "Managerial entrenchment and capital structure decisions." Journal of Finance, 52 (1997), 1411-1437.

Bethel, J., Liebeskind, J. and T. Opler. "Block share purchases and corporate performance." Journal of Finance, 53 (1998), 605-634.

Born, J. and V. McWilliams. "Insider equity ownership and financial leverage." Financial Management, 22(4) (1993), 19-21.

Bowman, R. "The importance of a market-value measurement of debt in assessing leverage." Journal of Accounting Research, 18(1) (1980), 242-254.

Bradley, M., Jarrell, G. and E. Kim. "On the existence of an optimal capital structure: Theory and evidence." Journal of Finance, 39(3) (1984), 857-880.

Chiarella, C., Pham, T., Sim A. and M. Tan. "Determinants of corporate capital structure: Australian evidence." Pacific-Basin Capital Markets Research, 3 (1992), 139-158.

Cho, M-H. "Ownership structure, investment, and the corporate value: An empirical analysis." Journal of Financial Economics, 47 (1998), 103-121.

Crutchley, C. and R. Hansen. "A test of the agency theory of managerial ownership, corporate leverage, and corporate dividends." Financial Management, 18(4) (1989), 36-46.

DeAngelo, H. and R. Masulis. "Optimal capital structure under corporate and personal taxation." Journal of Financial Economics, 8(1) (1980), 3-29. 
Demsetz, H. "The structure of ownership and the theory of the firm." Journal of Law and Economics, 26(2) (1983), 375-393.

Eddey, P., Lee, K.W. and S. Taylor. "What motivates going private?: An analysis of Australian firms." Accounting and Finance, 36(1) (1996), 31-50.

Fama, E. and M. Jensen. "Separation of ownership and control." Journal of Law and Economics, 26(2) (1983), 301-325.

Ferri, M. and W. Jones. "Determinants of financial structure: A new methodological approach." Journal of Finance, 34(3) (1979), 631-644.

Friend, I. and L. Lang. "An empirical test of the impact of managerial self-interest on corporate capital structure." Journal of Finance, 43(2) (1988), 271-281.

Gatward, P. and I. Sharpe. "Capital structure dynamics with interrelated adjustment: Australian evidence." Australian Journal of Management, 21(2) (1996), 89-112.

Grossman, S. and O. Hart. "Takeover bids, the free-rider problem and the theory of the corporation." Bell Journal of Economics, 11(1) (1980), 42-64.

Hermalin, B. and M. Weisbach. "The effects of board composition and direct incentives on firm performance." Financial Management, 20(4) (1991), 101-112.

Himmelberg, C., Hubbard, R. and D. Palia. "Understanding the determinants of managerial ownership and the link between ownership and performance." Journal of Financial Economics, 53 (1999), 353384.

Howard, P. and R. Brown. "Dividend policy and capital structure under the imputation tax system: Some clarifying comments." Accounting and Finance, 32(1) (1992), 51-61.

Jensen, G., Solberg, D. and T. Zorn. "Simultaneous determination of insider ownership, debt and dividend policies." Journal of Financial and Quantitative Analysis, 27(2) (1992), 247-263.

Jensen, M. and W. Meckling. "Theory of the firm: Managerial behaviour, agency costs and ownership structure." Journal of Financial Economics, 3(4) (1976), 305-360.

Jensen, M. "Agency costs of free cash flow, corporate finance, and takeovers." American Economic Review, 76(2) (1986), 323-329.

Johnson, S. "An empirical analysis of the determinants of corporate debt ownership structure." Journal of Financial and Quantitative Analysis, 32 (1997), 47-69.

Keasey, K., Short, H. and R. Watson. "Directors' ownership and the performance of small and medium sized firms in the UK" Small Business Economics, 6(3) (1994), 225-236.

Kim, W. and E. Sorensen. "Evidence on the impact of agency costs of debt on corporate debt policy" Journal of Financial and Quantitative Analysis, 21(2) (1986), 131-144.

Lehn, K. and A. Poulsen. "Free cash flow and stockholder gains in going private transactions." Journal of Finance, 44(3) (1989), 771-789.

Maddala, G. Introduction to Econometrics, Second Edition (Macmillan Publishing Company), (1992). 
Manne, H. "Mergers and the market for corporate control." Journal of Political Economy, 73(2) (1965), 110-120.

McConnell, J. and H. Servaes. "Additional evidence on equity ownership and corporate value." Journal of Financial Economics, 27(2) (1990), 595-612.

McConnell, J. and H. Servaes. "Equity ownership and the two faces of debt." Journal of Financial Economics, 39 (1995), 131-157.

Mehran, H. "Executive incentive plans, corporate control, and capital structure." Journal of Financial and Quantitative Analysis, 27(4) (1992), 539-560.

Modigliani F. and M. Miller. "The cost of capital, corporation finance, and the theory of investment." American Economic Review, 48(3) (1958), 261-297.

Morck, R., Shleifer, A. and R. Vishny. "Management ownership and market valuation." Journal of Financial Economics, 20(1/2) (1988), 293-315.

Myers, S. and N. Majluf. "Corporate financing and investment decisions when firms have information that investors do not have." Journal of Financial Economics, 13(2) (1984), 187-221.

Myers, S. “Determinants of corporate borrowing.” Journal of Financial Economics, 5(2) (1977), 147175.

Pound, J. "Proxy contests and the efficiency of shareholder oversight." Journal of Financial Economics, 20(1/2) (1988), 237-265.

Prowse, S. "Corporate governance in an international perspective." BIS Economic Papers, 41(July) (1994), 7-82.

Putterman, L. "Ownership and the nature of the firm." Journal of Comparative Economics, 17(2) (1993), 243-263.

Scott, D. and J. Martin. "Industry influence on financial structure." Financial Management, 4(1) (1975), 67-73.

Shleifer, A. and R. Vishny. "Large shareholders and corporate control." Journal of Political Economy, 94(3) (1986), 461-488.

Shome, D. and S. Singh. "Firm value and external blockholdings." Financial Management, 24(4) (1995), 3-14.

Short, H. and K. Keasey. "Managerial ownership and the performance of firms: evidence from the UK." Journal of Corporate Finance, 5 (1999), 79-101.

Smith, R. and J. Kim. "The combined effects of free cash flow and financial slack on bidder and target stock returns." Journal of Business, 67 (1994), 281-310.

Titman, S. and R. Wessels. "The determinants of capital structure choice." Journal of Finance, 43(1) (1988), 1-19.

Wald, J. "How firm characteristics affect capital structure: An international comparison." Unpublished Working Papers, Department of Economics, UC Berkeley, Berkeley, CA. (1995). 
Weisbach, M. "Corporate governance and hostile takeovers." Journal of Accounting and Economics, 16(1/2/3) (1993), 199-208.

White, H. "A heteroskedasticity-consistent covariance matrix estimator and a direct test for heteroskedasticity." Econometrica, 48 (1980), 817-838. 